\title{
Social influences on the metacognitive regulation of eyewitness memory reports
}

Citation for published version (APA):

Rechdan, J. (2017). Social influences on the metacognitive regulation of eyewitness memory reports. [Doctoral Thesis, Maastricht University, Department of Psychology, University of Portsmouth Portsmouth, United Kingdom.]. Datawyse / Universitaire Pers Maastricht. https://doi.org/10.26481/dis.20170628jr

Document status and date:

Published: 01/01/2017

DOI:

10.26481/dis.20170628jr

Document Version:

Publisher's PDF, also known as Version of record

\section{Please check the document version of this publication:}

- A submitted manuscript is the version of the article upon submission and before peer-review. There can be important differences between the submitted version and the official published version of record.

People interested in the research are advised to contact the author for the final version of the publication, or visit the DOI to the publisher's website.

- The final author version and the galley proof are versions of the publication after peer review.

- The final published version features the final layout of the paper including the volume, issue and page numbers.

Link to publication

\footnotetext{
General rights rights.

- You may freely distribute the URL identifying the publication in the public portal. please follow below link for the End User Agreement:

www.umlib.nl/taverne-license

Take down policy

If you believe that this document breaches copyright please contact us at:

repository@maastrichtuniversity.nl

providing details and we will investigate your claim.
}

Copyright and moral rights for the publications made accessible in the public portal are retained by the authors and/or other copyright owners and it is a condition of accessing publications that users recognise and abide by the legal requirements associated with these

- Users may download and print one copy of any publication from the public portal for the purpose of private study or research.

- You may not further distribute the material or use it for any profit-making activity or commercial gain

If the publication is distributed under the terms of Article $25 \mathrm{fa}$ of the Dutch Copyright Act, indicated by the "Taverne" license above, 


\section{Summary}

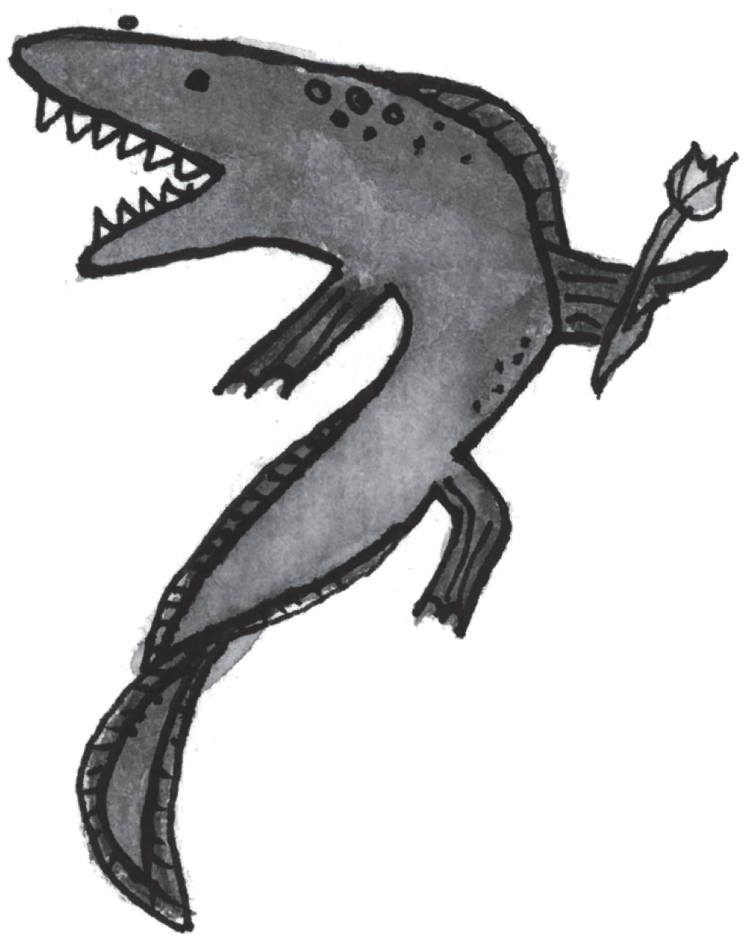



Eyewitness testimony is important to legal procedures. However, eyewitnesses are sometimes exposed to post-event factors that can distort their memory reports. The aim of this thesis was to explore the effects of social influences on the metacognitive monitoring and control processes that regulate memory reporting. In five experiments, we exposed participants to social comparative information (Experiments 1,2 and 3) and misinformation from a co-witness (Experiments 4 and 5) and examined the effects of these manipulations on i) participants' subjective confidence in the accuracy of their recall, ii) the precision of the details they volunteered, and iii) their tendency to withhold responses. In Experiment 1, participants $(N=87)$ were given negative, positive, or no information about a cowitness's performance on a cued recall task comprised of questions about a mock crime. Participants then independently answered cued recall questions about the event. Participants exposed to information about a co-witness' performance (negative or positive) reported more precise (fine-grain) details than those in the no information control group. Selection of fine-grain responses positively correlated with participants' confidence in the accuracy of these responses. However, confidence in fine-grain responses did not differ significantly between participants in the control and experimental groups. In Experiment 2, participants $(N=90)$ watched a video of a mock crime event and then completed a practice task in which they answered questions about the event. Participants in the experimental groups received either positive or negative feedback about their accuracy on the practice task, which compared their performance to that of others. Control participants received no feedback. Receiving feedback did not significantly affect participants' confidence, accuracy, or their grain size selection in comparison to the control group. In Experiment 3, participants $(N=92)$ watched a video of a mock crime event and completed cued recall questions about one of the characters in the video. Participants in the experimental groups then took turns verbally reporting their answers with a confederate who either confidently agreed (confirming condition) or disagreed (disconfirming condition) with the majority of their answers. Participants in the control condition did not report their answers verbally. Participants then completed another set of cued recall questions about the event and provided confidence ratings. Participants in the disconfirming condition included fewer finegrain details in their memory reports (cf. those in the confirming and control conditions). In Experiment 4, participants $(N=66)$ watched one of two versions of a video depicting a mock crime event. Video versions differed with respect to two critical items. Participants in the discussion condition then discussed the event with a co-witness who had seen a different version of the video; participants in the control condition did not discuss the event. Participants then completed a cued recall task comprised of questions about the crime. Participants who discussed the event with a co-witness reported more incorrect details (mentioned by the co-witness) in 
the cued recall task than those in the control condition. Co-witness discussion did not significantly affect the meta-cognitive regulation of participants' subsequent memory reports. In Experiment 5, participants $(N=60)$ watched a video of a mock crime event and then read one of two versions of a bogus co-witness report, each of which contained three different items of misinformation. Participants then answered cued recall questions about the event. Participants were significantly less accurate when answering questions about critical items (cf. non-critical items), but confidence, fine-grain volunteering, and response withholding were not significantly different for critical item questions (cf. non-critical item questions). Overall, the results of the present thesis demonstrate that social conditions can affect metacognitive regulation of the content of individual memory reports. The five experiments that comprise this thesis represent the first programme of research to examine social influence effects on the meta-memorial monitoring and control processes that govern memory reporting. Avenues for further research on this topic are discussed in light of the present findings. 